\title{
Response of the blue shrimp Litopenaeus stylirostris to temperature decrease and hypoxia in relation to molt stage \\ Chantal Mugnier ${ }^{* 1}$ and Claude Soyez ${ }^{2}$
}

1 : Laboratoire d'Aquaculture Calédonien, IFREMER, BP2059, 98846 Nouméa Cedex, New Caledonia

2 : Laboratoire d'Aquaculture Tropicale, IFREMER, Taravao, Tahiti

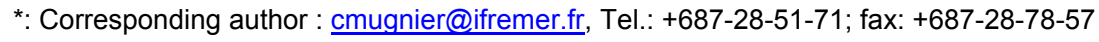

\begin{abstract}
:
The effect of different levels of dissolved oxygen (DO) and a decreased temperature combined with severe hypoxia were studied in the blue shrimp Litopenaeus stylirostris in relation to molt stage. In the first experiment, shrimps were submitted to DO concentrations of 5 to $1 \mathrm{mg} \mathrm{I}^{-1}$. Osmoregulatory capacity (OC) was measured in shrimps at molt stage $C$ after 6,24 , or $48 \mathrm{~h}$ of exposure. No mortality was recorded but a significant negative effect of DO concentration on hypo-OC was observed for DO concentrations below $3 \mathrm{mg} \mathrm{l}^{-1}$. Osmoregulation improved after $48 \mathrm{~h}$ exposure, compared to 6 and $24 \mathrm{~h}$ exposure.
\end{abstract}

In a second experiment, temperature was decreased from 28 to $22^{\circ} \mathrm{C}$ in $24 \mathrm{~h}$, before a severe hypoxia of $0.5 \pm 0.1 \mathrm{mg} \mathrm{O}_{2} \mathrm{I}^{-1}$ was applied. Mortality and OC were studied in relation to molt stages. Half of the shrimps died after respectively $100 \mathrm{~min}$ at $0.5 \mathrm{mg} \mathrm{O}_{2} \mathrm{I}^{-1}$ at $28^{\circ} \mathrm{C}$ and $153 \mathrm{~min}$ at $0.4 \mathrm{mg} \mathrm{O}$ $1^{-1}$ at $22^{\circ} \mathrm{C}$. Mortality was significantly higher in stages $D_{2}$ and $B$ compared to stages $C$ and $D_{0}$. Control shrimps in stage $D_{2}$ had a lower hypo-OC than shrimps in stages $C$ and $D_{0}$ both at 28 and $22^{\circ} \mathrm{C}$. Temperature decrease had no effect on hypo-OC. Hypoxia reduced hypo-OC for all stages, whatever the temperature, but the effect was greater in stage $\mathrm{C}$ at $27^{\circ} \mathrm{C}\left(68 \%\right.$ decrease) compared to $22^{\circ} \mathrm{C}$ $(49 \%)$ and stage $\mathrm{D}_{2}$ at both temperatures (respectively, $43 \%$ and $58 \%$ at 27 and $22{ }^{\circ} \mathrm{C}$ ). Combination of temperature and hypoxia had a significant effect on hypo-OC. Low temperature reduced the effect of hypoxia presumably by slowing down the metabolism. Results are discussed in relation to pond observation. 


\section{Introduction}

Shrimp farming in New Caledonia is dedicated to the blue shrimp Litopenaeus stylirostris in earthen ponds. Although it is a developing industry, it is facing episodes of mortality due to a pathogenic bacteria Vibrio penaeicida. The disease appears mainly at the inter-season periods, although most of the shrimps carry the Vibrio throughout the years and are apparently healthy (Goarant, pers. comm.). Drops of water temperature seem to have an impact on mortalities (Mermoud et al., 1998) but are not sufficient to trigger off the disease. Other external and/or internal (such as molt stage) factors may be implied. Dissolved oxygen (DO) concentration in ponds is one of the main environmental factors which often undergoes large fluctuations and can induce a stress in shrimp, especially in semi-intensive culture system for which no air supply is provided in the ponds. During the last phase of grow-out in ponds without aeration, shrimps can be punctually exposed to short-term hypoxia (oxygen level from $3 \mathrm{mg} \mathrm{l}^{-1}$ to less than $1 \mathrm{mg} \mathrm{l}^{-1}$ ). Short-term decreases of DO concentration can have a negative effect on shrimp immune system (Direkbusarakom and Danayadol, 1998; Le Moullac et al., 1998; Le Moullac and Haffner, 2000), and may decrease resistance to diseases. It has also been shown that $\underline{L}$. stylirostris subjected to diurnal cycles of $1.5 \mathrm{mg} \mathrm{O}_{2} \mathrm{l}^{-1}$ to saturation presented lowered survival and growth, and their molting cycle was modified (Aquacop et al., 1988). Long-term hypoxia can affect molting (Clark, 1986) and growth (Ocampo et al., 2000). It has also been shown that depending of their molt stage shrimps can be more or less sensitive to stress (Wajsbrot et al., 1990), or experimental infection with pathogenic bacteria (Le Moullac et al., 1997; Cheng et al., 2003).

In the present study, two experiments were conducted in order to evaluate the effect of (1) DO concentrations and (2) a temperature decrease followed by hypoxia, on the survival and physiological status of juvenile L. stylirostris in relation to molt stage. In a first experiment juvenile L. stylirostris were subjected to different DO concentrations and sampled after 6, 24 or 48 hours of exposure, in order to define from which DO concentration, in relation to duration of exposure, shrimps become physiologically affected. In a second experiment, $\underline{\mathrm{L}}$. stylirostris were subjected to severe hypoxia at two different temperatures. The decreasing temperature applied in the experiment corresponded to natural variations observed in ponds during inter-season in New Caledonia. In both experiments mortality was recorded and osmoregulatory capacity (OC), which is a sensitive indicator for detecting physiological stress 
(Lignot et al., 2000), was measured in intermolt (experiment 1 and 2) and late premolt shrimps (experiment 2). OC is the difference in osmotic pressures between haemolymph and surrounding water at a given salinity (Charmantier et al., 1989). Osmoregulation, which maintains osmotic homeostasis, is one of the main regulatory functions in aquatic animal (Péqueux, 1995). L stylirostris is a good hypo-osmoregulator in sea water which OC may be affected by stressors such as ammonia exposure (Mugnier and Justou, 2004), organophosphorus insecticide exposure (Lignot et al., 1998) or low temperatures (Lemaire et al., 2002).

\section{Material and methods}

\subsection{Molt stage determination}

Six molt stages were defined according to the retraction of the epithelium within setae of the antennal scale (Drach, 1939; Chan et al., 1988). Shrimps were classified as A and B for respectively the early and late postmolt stages, $C$ for intermolt and $D_{0}, D_{1}, D_{2}$ for premolt stages. $\mathrm{D}_{2}$ was the late premolt stage prior to ecdysis, when epidermis is at maximal retraction and it is possible to distinguish the developing seta.

\subsection{Experimental animals}

The experiments took place in the Tropical Aquaculture Laboratory of IFREMER in Tahiti (French Polynesia). L. stylirostris were reared in earthen pond. Juvenile shrimps of 9-10 g weight were transferred to indoor tanks containing $75 \mathrm{l}$ of sea water, which was recirculated (experiment 1) or either recirculated or flow-through (8 tanks each, experiment 2). Densities were respectively 45 and 22 shrimps/tank in experiments 1 and 2 . Temperature was $28^{\circ} \mathrm{C}$, salinity 36\% and the osmotic pressure of the water $1057 \mathrm{mOsm} \mathrm{kg}^{-1}$ in both experiments. Shrimps were fed commercial pellets. They were not fed 12 hours before, and during, the experiment. Juvenile shrimps were acclimated for at least 2 days before experiments started (Soyez, 1997). 
2.3. Effect of different dissolved oxygen concentrations on mortality and osmoregulatory capacity

DO concentration was maintained to saturation (6-7 $\mathrm{mg} \mathrm{l}^{-1}$ ) before the experiment started and during the experiment for control shrimps. For challenged shrimps, the desired DO concentrations were the result of shrimp oxygen consumption. The surface of the water was covered with a plastic film to limit gas exchange at the surface. Required DO concentration was maintained by continuous monitoring of oxygen pressure $\left(\mathrm{PO}_{2}\right)$ with an Orbisphere oxymeter by opening or closing air electrovalves to adjust oxygen level. DO concentrations were maintained at 5, 4, 3, 2 and $1 \mathrm{mg} \mathrm{O}_{2} \mathrm{l}^{-1}$. Shrimps were maintained during 6, 24 or 48 hours at the concentrations cited. Mortality was recorded at the end of the experiment. Haemolymph samples of shrimps in stage $C$ were collected via the ventral sinus using disposable syringes and needles. Osmotic pressure of haemolymph was immediately measured on a Wescor 5500R vapor pressure osmometer. Osmotic pressure of the water was also measured for the calculation of OC.

\subsection{Effect of temperature decrease and severe hypoxia on mortality and hypo-OC}

The experimental procedure is shown on fig. 1. Temperature was gradually decreased from $28^{\circ} \mathrm{C}$ to $22^{\circ} \mathrm{C}$ in $24 \mathrm{~h}$ in 8 tanks out of 16 . Dissolved oxygen level was maintained between 6 and $7 \mathrm{mg} . \mathrm{l}^{-1}$ by constant aeration before the experiment started for all tanks, and during the experiment for control tanks at both 28 and $22^{\circ} \mathrm{C}$. The decrease of DO concentration ( 4 tanks for each temperature) was the result of shrimp oxygen consumption after the supplies in water and air were stopped, and the surface of the water covered with a plastic film to limit gas exchange at the surface. Shrimps were sampled for osmotic pressure as in experiment 1 in two tanks out of 4 for each treatment when DO concentration reached $0.6 \mathrm{mg} \mathrm{l}^{-1}$. Because there were not enough animals at stages $\mathrm{A}, \mathrm{B}$ and $\mathrm{D}_{1}$ either at $22^{\circ} \mathrm{C}$ or at $28^{\circ} \mathrm{C}$, only shrimps in stages $C, D_{0}$ and $D_{2}$ were sampled. Oxygen concentration was frequently monitored using an Orbisphere oxymeter in the remaining tanks. Each time a dead shrimp was observed in the tanks it was removed and the molt stage determined. The experiment was stopped when half of the shrimps were dead. The molt stage of the survival shrimps was also recorded. Control shrimps were sampled at the end of the experiment. 


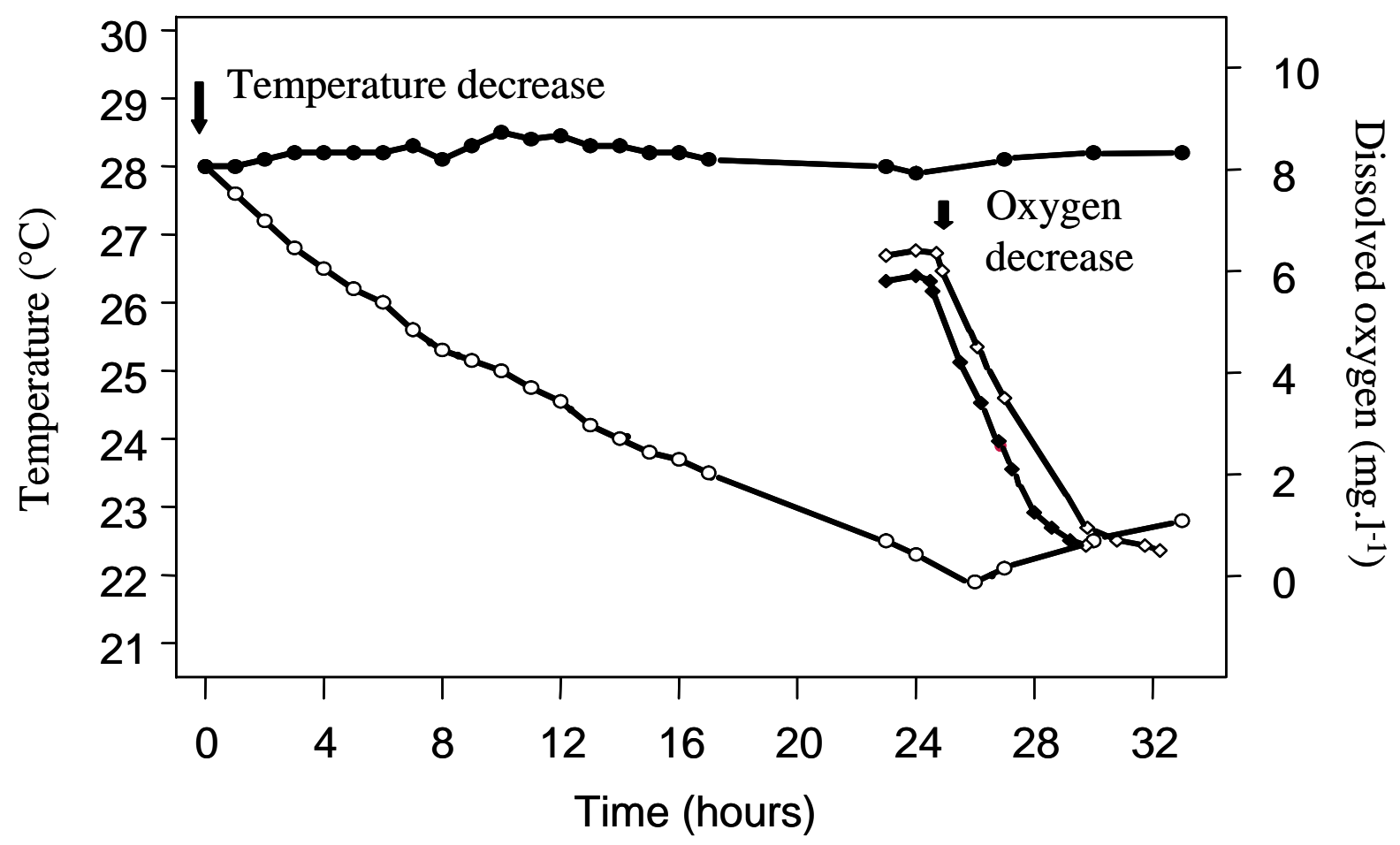

Fig. 1. Kinetic of experimental temperature and oxygen decreases applied on L. stylirostris in the second experiment. Open symbol: $22^{\circ} \mathrm{C}$; black symbols: $28^{\circ} \mathrm{C}$.

\subsection{Data and statistical analysis}

The OC was calculated as the difference between the osmotic pressure of seawater and shrimp haemolymph. The data were expressed as the mean \pm standard error of the mean, except for mortality expressed in percentage. Data of the first experiment are shown as the depression of OC compared to the control for each time studied. Data were analysed with two-way and oneway ANOVA followed by the PLSD Fisher test at the significant threshold of 5\% (Statview computer software). Differences in mortality between shrimp at different molt stages were analysed by Chi-square tests at the level of significant threshold of $5 \%$. 


\section{Results}

\subsection{Effect of different dissolved oxygen concentrations (figure 2)}

No mortality was recorded during the experiment. There was a significant effect of DO concentration on hypo-OC $(\mathrm{p}<0.0001)$. A decrease in hypo-OC of shrimps maintained at 1 and $2 \mathrm{mg} \mathrm{O}_{2} \mathrm{l}^{-1}$ was observed compared to shrimps maintained at 3, 4, 5 and 6 (control) $\mathrm{mg}$ $\mathrm{O}_{2} \mathrm{I}^{-1}$. Duration of exposure to the different DO concentrations had also a significant effect on hypo-OC $(\mathrm{p}<0.0001)$ for DO concentrations below $3 \mathrm{mg} \mathrm{l}^{-1}$. Hypo-OC was significantly higher after 48 hours exposure than after 6 and 24 hours. The combined effect of DO level with duration of exposure was significant $(\mathrm{p}=0.0035)$.

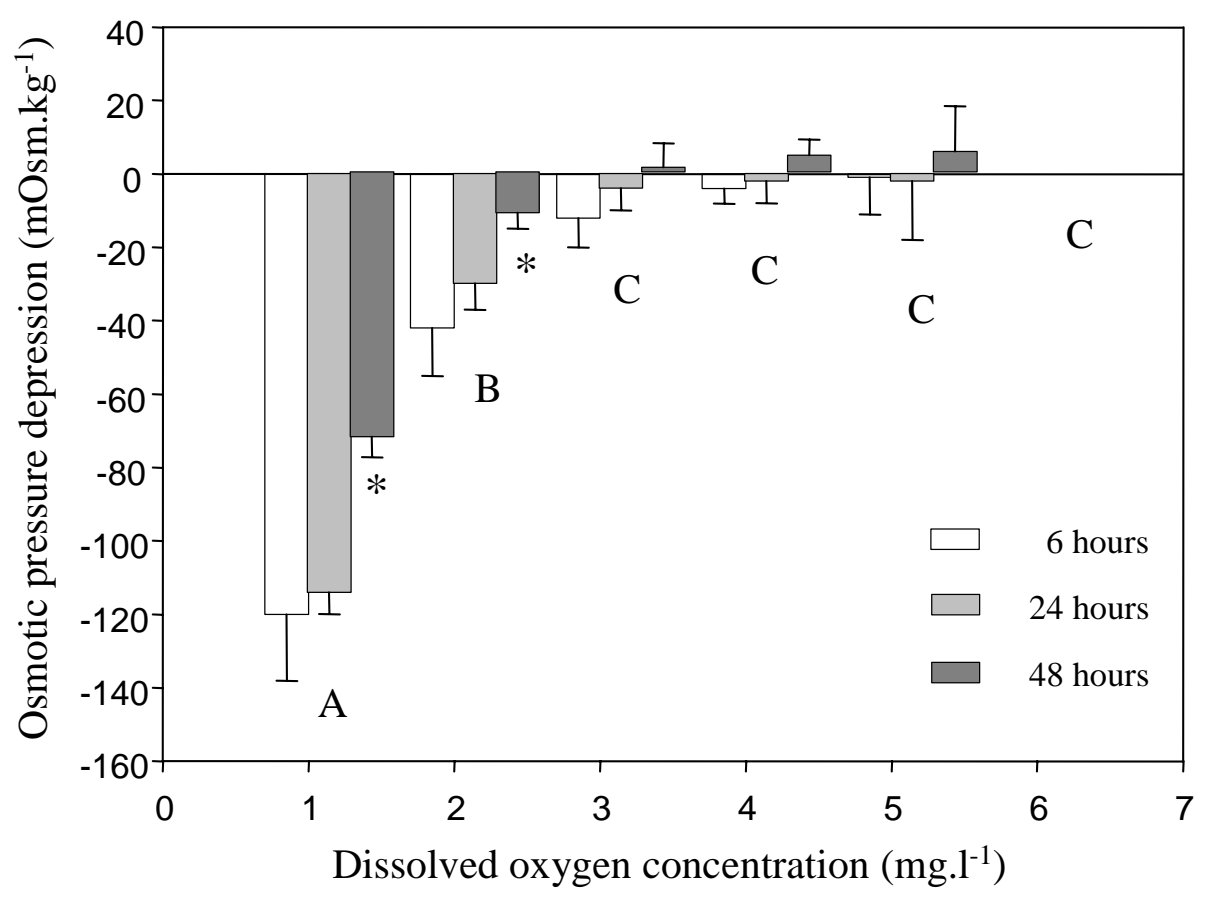

Fig. 2. Osmotic pressure depression (mean \pm S.E.) in L. stylirostris submitted to different dissolved oxygen level for different times of exposure in comparison with the control groups maintained at $6 \mathrm{mg} \mathrm{O}_{2} \mathrm{l}^{-1}$. Significant differences between groups are indicated by different capital letters $(\mathrm{P}<0.05)$. *Bars within group are significantly different $(\mathrm{P}<0.05)$. 


\subsection{Effect of hypoxia and temperature decrease}

No mortality was recorded in tanks maintained under normoxia at both $28^{\circ} \mathrm{C}$ and $22^{\circ} \mathrm{C}$. A reduction in locomotry activities was observed as DO concentration declined in hypoxic conditions. Below $1.5 \mathrm{O}_{2} \mathrm{mg} \mathrm{l}^{-1}$, all the shrimps got together and stayed very still. Mortality started 24 min after oxygen level reached $0.6 \mathrm{mg} \mathrm{l}^{-1}$ at $28^{\circ} \mathrm{C}$ and after $135 \mathrm{~min}$ at $22^{\circ} \mathrm{C}$ when oxygen level reached $0.45 \mathrm{mg} \mathrm{l}^{-1}$. It took $100 \mathrm{~min}$ at $28^{\circ} \mathrm{C}$ and $153 \mathrm{~min}$ at $22^{\circ} \mathrm{C}$ to have $50 \%$ of the shrimps dead. DO concentration in tanks maintained at $22^{\circ} \mathrm{C}$ was as low as $0.35 \mathrm{mg} \mathrm{l}^{-1}$ when the experiment was stopped. The initial temperature of $22^{\circ} \mathrm{C}$ increased slightly to $22.5^{\circ} \mathrm{C}$ when DO level was close to $0.6 \mathrm{mg} \mathrm{l}^{-1}$, and $22.7^{\circ} \mathrm{C}$ at the end of the experiment.

Mortalities in relation to molt stages are presented on figure 3. No animals in stage $\mathrm{D}_{2}$ were observed at $22^{\circ} \mathrm{C}$. There was no significant differences $(\mathrm{p}=0.920)$ between the other stages. Mortality was significantly higher for shrimps in advanced premolt stage $\mathrm{D}_{2}$ and postmolt stage $\mathrm{B}$ than for intermolt and early premolt shrimps $\left(\mathrm{C}\right.$ and $\left.\mathrm{D}_{0}\right)$ at $28^{\circ} \mathrm{C}$.
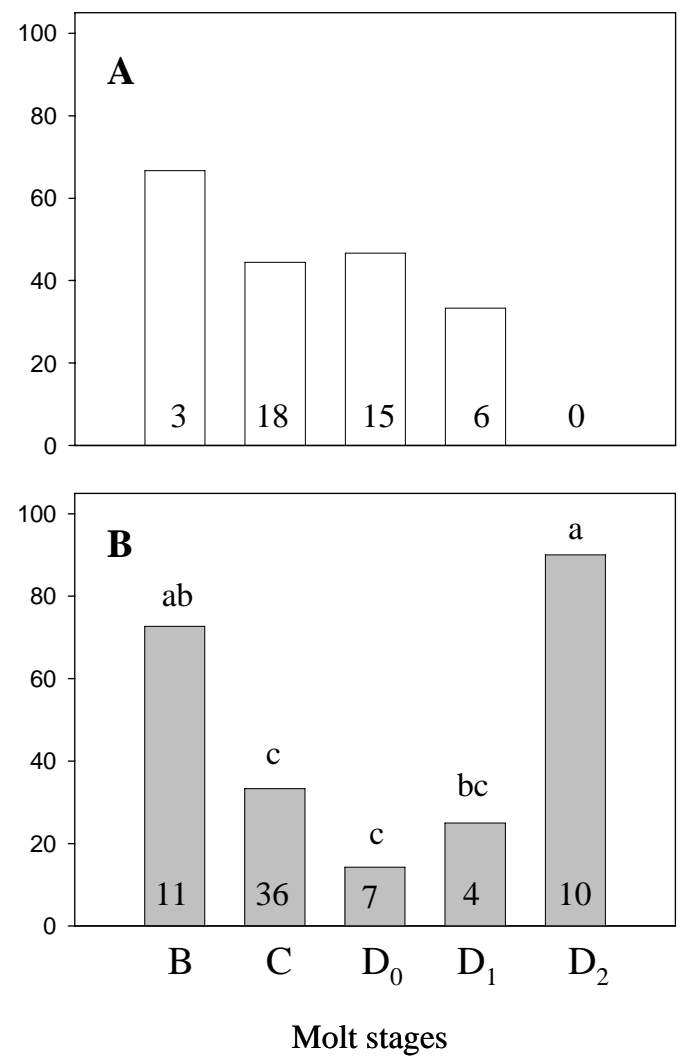

Fig. 3. Percentage of mortality for each molt stage at $22^{\circ} \mathrm{C}(\mathrm{A})$ and $27^{\circ} \mathrm{C}$ (B) in $\underline{\mathrm{L} \text {. stylirostris }}$ submitted to hypoxia. Number of animals are indicated into bars. Bars with different letters are significantly different $(\mathrm{p}<0.05)$. 
Hypo-OC values of shrimps in relation to treatment and molt stage are shown in Table 1. Temperature decrease had no significant effect on hypo-OC in shrimps maintained under normoxia whatever the molt stage. Mean hypo-OC of shrimps in stage $\mathrm{D}_{2}$ under normoxia was significantly lower than that of shrimps in stages $C$ and $D_{0}$ at both temperatures. The difference was $14 \%$ at $28^{\circ} \mathrm{C}$ and $11 \%$ at $22^{\circ} \mathrm{C}$. No significant differences were observed between molt stages in shrimps under hypoxia, whatever the temperature. Hypoxia led to a significant decrease of hypo-OC for all stages, whatever the temperature. Stage $(p=0.0073)$, treatment $(\mathrm{p}<0.001)$ and combination of both $(\mathrm{p}=0.006)$ had a significant effect on hypo-OC. Hypo-OC of shrimps in stage $\mathrm{C}$ under hypoxia was significantly lower at $28^{\circ} \mathrm{C}$ compared to $22^{\circ} \mathrm{C}$ (Table 1). No difference was observed for shrimps in stage $\mathrm{D}_{2}$. Comparison was not possible for stage $\mathrm{D}_{0}$ (no data). For animals in stage $\mathrm{C}$, hypoxia led to a $68 \%$ decrease of hypo-OC at $28^{\circ} \mathrm{C}$ compared to the control, and $49 \%$ at $22^{\circ} \mathrm{C}$. Decreases were respectively $43 \%$ and $58 \%$ for shrimps in stage $\mathrm{D}_{2}$, and $53 \%$ for stage $\mathrm{D}_{0}$ at $22^{\circ} \mathrm{C}$.

\section{Table 1}

Hypo-osmoregulatory capacity (mOsm. $\mathrm{kg}^{-1}$ ) in relation to temperature and oxygen treatment of $\underline{L}$. stylirostris according to the molt stage (experimentation 2) (mean \pm S.E, (n))

\begin{tabular}{|c|c|c|c|c|c|}
\hline & \multicolumn{2}{|c|}{$28^{\circ} \mathrm{C}$} & \multicolumn{2}{|c|}{$22^{\circ} \mathrm{C}$} & \\
\hline & Normoxia & Hypoxia & Normoxia & Нypoxia & \\
\hline \multirow[t]{2}{*}{ Stage C } & $-232.7 \pm 13.5^{a}$ & $-73.9 \pm 10.7^{c}$ & $-228.6 \pm 7.5^{a}$ & $-116.4 \pm 8.8^{b}$ & \multirow[t]{2}{*}{$\mathrm{P}<0.0001$} \\
\hline & (3) & (18) & (10) & (10) & \\
\hline \multirow[t]{2}{*}{ Stage D0 } & $-214.2 \pm 6.9^{a}$ & - & $-220.6 \pm 6.8^{a}$ & $-116.4 \pm 15.6^{b}$ & \multirow[t]{2}{*}{$\mathrm{P}<0.0001$} \\
\hline & (11) & (0) & (13) & (5) & \\
\hline \multirow[t]{3}{*}{ Stage D2 } & $-181.5 \pm 9.2^{a^{*}}$ & $-102.6 \pm 11.2^{b}$ & $-199.0 \pm 6.1^{\mathrm{a}^{*}}$ & $-83.4 \pm 7.8^{b}$ & \multirow[t]{3}{*}{$\mathrm{P}<0.0001$} \\
\hline & (15) & (8) & (16) & (7) & \\
\hline & $* \mathrm{P}<0.05$ & $\mathrm{P}>0.05$ & $* \mathrm{P}<0.05$ & $\mathrm{P}>0.05$ & \\
\hline
\end{tabular}

Significant differences for each molt stage are shown by different letters

* indicates difference between molt stages for each treatment 


\section{Discussion}

\subsection{Effect of oxygen depression}

In experimental conditions, DO concentrations from $3 \mathrm{mg} \mathrm{O}_{2} \mathrm{l}^{-1}$ and above had no effect on

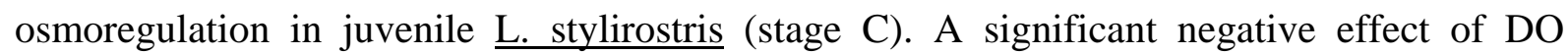
concentration on hypo-OC was observed for concentrations below $3 \mathrm{mg} \mathrm{O}_{2} \mathrm{l}^{-1}$, as it was also observed in $\underline{\text { P. vannamei }}$ (Charmantier et al., 1994). However, no mortality was recorded over the 48 hours, while Allan and Maguire (1991) observed $16.7 \%$ mortality over $48 \mathrm{~h}$ of

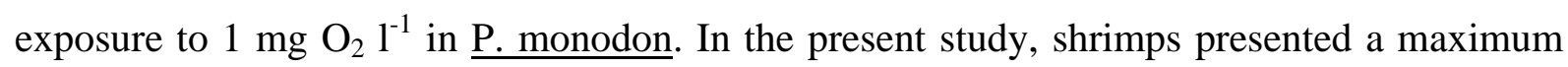
stress response (lowest hypo-OC) after 6 hours of exposure to low DO concentration, and this response seemed to be maintained after 24 hours exposure. However this negative effect tended to decrease with time, as shown by a higher hypo-OC after 48 hours exposure, possibly because the shrimps adapted partially to the low concentration of DO. Moreover, Soyez (1997) showed that L. stylirostris exposed to a constant DO of $2 \mathrm{mg} \mathrm{l}^{-1}$ over a month did not show any mortality nor reduction in growth, while $\underline{P \text {. semisulcatus }}$ exposed to a longterm DO stress of $2 \mathrm{mg} \mathrm{O}_{2} \mathrm{l}^{-1}$ for 17 days, showed mortality and molting was inhibited (Clark, 1986). These results seem to indicate that $\underline{L}$. stylirostris is relatively well resistant to hypoxia. However, subjected to diurnal-like cycles of $1.5 \mathrm{mg} \mathrm{O}_{2} \mathrm{l}^{-1}$ to saturation, $\underline{\mathrm{L} \text {. stylirostris }}$ presented lowered survival and growth, and their molting cycle was modified (Aquacop et al., 1988). The results of the present study coupled to those of Soyez (1997) and Aquacop et al. (1988) tend to indicate that repetition of stress such as a low DO level is more stressful than a single acute or a long term hypoxia. The results of Allan and Maguire (1991), who did not observe any reduction in growth over 21 days in $\underline{P}$. monodon exposed to a single acute DOstress enhance the limited effect of an acute stress.

No mortality was recorded for a DO concentration of $1 \mathrm{mg} \mathrm{l}^{-1}$ at $28^{\circ} \mathrm{C}$, even after $48 \mathrm{~h}$ of exposure. However, as shown in experiment 2, less than $30 \mathrm{~min}$ at $0.6 \mathrm{mg} \mathrm{O}_{2} \mathrm{l}^{-1}$ seems to be the tolerance limit before mortality started at this temperature. In less than two hours half of

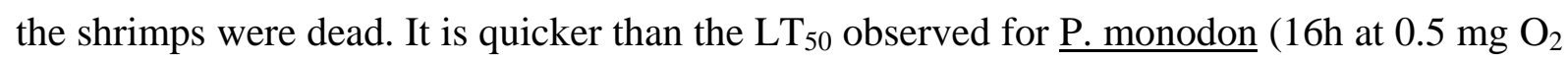
$\mathrm{l}^{-1}, 27 .{ }^{\circ} \mathrm{C}$ ) (Allan and Maguire, 1991), or Metapenaeus ensis (399 min at $0.5 \mathrm{mg} \mathrm{O}_{2} \mathrm{l}^{-1}$, $22^{\circ} \mathrm{C}$ ) (Wu et al., 2002), but experimental conditions are different and make the comparison difficult as in the present study the shrimps were under stressful DO level (less than $3 \mathrm{mg} \mathrm{\textrm {O } _ { 2 }}$ $\mathrm{l}^{-1}$ ) 6 hours before the level reached $0.6 \mathrm{mg} \mathrm{O}_{2} \mathrm{l}^{-1}$. In shrimp pond such a continuous decrease 
of DO level is observed during the night, due to the consumption of oxygen by phytoplankton. The present results indicate that consequences could be dramatic if oxygen level decrease below $1 \mathrm{mg} \mathrm{O}_{2} \mathrm{l}^{-1}$ and does not go up to $3 \mathrm{mg} \mathrm{O}_{2} \mathrm{l}^{-1}$ quickly enough, all the more since it is repeated for several days or happening when most of the shrimp are molting.

\subsection{Effect of temperature decrease}

In our experimental conditions, a temperature decrease of $6^{\circ} \mathrm{C}$ in 24 hours had no effect neither on survival nor ionic regulation in both pre- and intermolt shrimps, while in pond such a decrease till $22^{\circ} \mathrm{C}$ is often followed by mortality outbreaks. The main hypotheses concerning the origin of the difference of response between pond and experimental facilities are: (1) the repetition of such temperature decreases due to diurnal variations in pond could be more stressful than a single isolated decrease as observed for DO (Aquacop et al., 1988), and/or (2) the temperature effect could be toward the pathogen (increase in number and/or virulence) (Goarant et al., 2000), and/or (3) associated with the pathogen: an environmental stress following an experimental infection with a pathogenic bacteria may increase mortality (unpublished data) and/or eventually (4) the temperature decrease could be associated with other stressful factors and act in synergy. Indeed, levels of one or more parameters such as DO, ammonia, $\mathrm{pH}$, or nitrites in ponds may be close to the tolerance limits of the shrimp as the same time as the temperature decrease (Boyd, 1982) and may have a synergic effect. For instance, it was observed that DO levels below 55\% saturation increased toxicity of ammonia

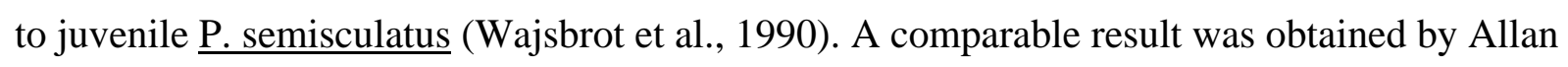
et al. (1990) on P. monodon.

\subsection{Combined effect of temperature decrease and hypoxia}

Association of oxygen depression with a lower temperature had no effect (stage $\mathrm{D}_{2}$ ) or a positive effect (stage C) on shrimp osmoregulation and tolerance to hypoxia compared to $28^{\circ} \mathrm{C}$. A lower temperature seems to increase tolerance of shrimps to hypoxia, as shown by a hypo-OC which was less depressed at $22^{\circ} \mathrm{C}$ than at $28^{\circ} \mathrm{C}$. This effect was not observed for stage $\mathrm{D}_{2}$ for which the hypo-OC was already lower at $28^{\circ} \mathrm{C}$ compared to stage C. It was previously observed for L. stylirostris (Lignot et al., 1999; Mugnier and Justou, 2004) and for

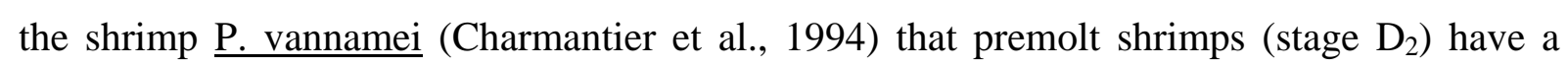
lower hypo-OC than intermolt animals at DO saturation level. The increase in osmolality could be associated to the beginning of a water uptake at molt. The lack of negative 
combined effect of temperature decrease and hypoxia could be due to a slower metabolism and a decrease in oxygen need at $22^{\circ} \mathrm{C}$, as it was observed in the freshwater prawn Macrobrachium rosenbergii. In this species, a 30\% decrease of oxygen uptake was observed between $27^{\circ} \mathrm{C}$ and $22^{\circ} \mathrm{C}$ (Chen and Kou, 1996). It is observed in general that power of metabolic regulation tends to decrease with increase of ambient temperature, possibly in relation to an increase of metabolism and limits due to the adaptability of oxygen-carrying systems from ambient medium to the cells (Truchot and Jouve-Duhamel, 1983). However, there are species like the shrimp $\underline{P}$. japonicus for which on the contrary regulation power increases till temperatures around $26-30^{\circ} \mathrm{C}$ (Truchot and Jouve-Duhamel, 1983), but $\underline{\mathrm{L}}$.

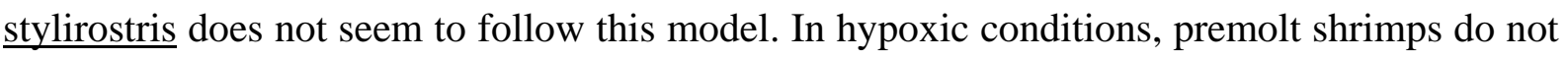
seem to be more sensitive to oxygen stress than intermolt shrimps, in term of hypo-OC depression, possibly because the osmoregulation is already lower for this stage compared to

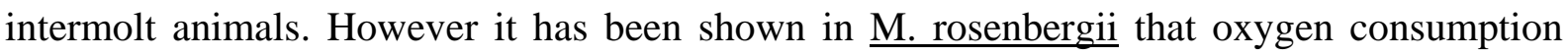
increased during the premolt and molt stages (Stern and Cohen, 1982). The authors suggested that more carbone is being utilized for metabolic requisites, and not for tissue growth and organic reserve accumulation as in the intermolt stage. However, a higher mortality rate in our experiment indicates that $\mathrm{D}_{2}$ shrimp are more affected by hypoxia than intermolt animals at $28^{\circ} \mathrm{C}$.

DO levels below $3 \mathrm{mg} \mathrm{O}_{2} \mathrm{l}^{-1}$ are observed in ponds during the inter season when temperature drops and mortalities occur. The present results tend to show that the combination of both factors can not explain the mortality outbreaks. It confirms the probable pluri-factorial and complex origin of these outbreaks and that more studies are needed, particularly on the relation between the pathogen, the shrimp and the environment.

\section{Aknowledgements}

This work was supported by research grants from the North and South Provinces of New Caledonia. The first author would like to thank the Laboratory in Tahiti for the use of its facilities. 


\section{References}

Allan, G. L., Maguire, G. B., 1991. Lethal levels of low dissolved oxygen and effects of short-term oxygen stress on subsequent growth of juvenile Penaeus monodon. Aquaculture 94, 27-37.

Allan, G. L., Maguire, G. B., Hopkins, S. J., 1990. Acute and chronic toxicity of ammonia to juvenile Metapenaeus macleayi and Penaeus monodon and the influence of low dissolvedoxygen levels. Aquaculture 91, 265-280.

Aquacop, Bédier, E., Soyez, C., 1988. Effects of dissolved oxygen concentration on survival and growth of Penaeus vannamei and Penaeus stylirostris. J. World Aquac. Soc. 19, 13A.

Boyd C.E., 1982. Water quality management for pond fish culture. Developments in aquaculture and Fisheries Science, vol. 9. Elsevier, Amsterdam, 318 pp.

Chan, S.-M., Rankin, S. M., Keeley, L. L., 1988. Characterization of the molt stages in Penaeus vannamei: setogenesis and hemolymph levels of total protein, ecdysteroids, and glucose. Biol. Bull. 175, 185-192.

Charmantier, G., Bouaricha, N., Charmantier-Daures, M., Thuet, P., Trilles, J.-P., 1989. Salinity tolerance and osmoregulatory capacity as indicators of the physiological state of penaeid shrimps. European Aquaculture Society special Publication 10, 65-66.

Charmantier, G., Soyez, C., Aquacop, 1994. Effect of molt stage and hypoxia on osmoregulatory capacity in the penaeid shrimp Penaeus vannamei. J. Exp. Mar. Biol. and Ecol. 178, 233-246.

Chen, J.-C., Kou, T.-T., 1996. Effects of temperature on oxygen consumption and nitrogenous excretion of juvenile Macrobrachium rosenbergii. Aquaculture 145, 295-303.

Cheng, W., Juang, F.-M., Li, J.-T., Lin, M.-C., Liu, C.-H., Chen, J.-C., 2003. The immune response of the giant freshwater prawn Macrobrachium rosenbergii and its susceptibility to Lactococcus garvieae in relation to the moult stage. Aquaculture 218, 33-45.

Clark, J. V., 1986. Inhibition of moulting in Penaeus semisulcatus (De Haan) by long-term hypoxia. Aquaculture 52, 253-254.

Direkbusarakom, S., Danayadol, Y., 1998. Effect of oxygen depletion on some parameters of the immune system in black tiger shrimp (Penaeus monodon). In "Advances in shrimp biotechnology” (T. W. Flegel, ed.), pp. 147-149. National Center for Genetic Engineering and Biotechniology, Bangkok, Thailand.

Drach P., 1939. Mue et cycle d’intermue chez les crustacés décapodes. Annales de l’Institut Océanographique de Paris N. S. 19, 103-391. 
Goarant, C., Herlin, J., Brizard, R., Marteau, A.-L., Martin, C., Martin, B., 2000. Toxic factors of Vibrio strains pathogenic to shrimp. Dis. Aquat. Org. 40, 101-107

Lemaire, P., Bernard, E., Martinez-Paz, J.-A., Chim, L., 2002. Combined effect of temperature and salinity on osmoregulation of juvenile and sub-adult Penaeus stylirostris. Aquaculture 209, 307-317.

Le Moullac, G., Le Groumellec, M., Ansquer, D., Froissard, S., Lecy, P., Aquacop, 1997. Haematological and phenoloxidase activity changes in the shrimp Penaeus stylirostris in relation with the moult cycle: protection against vibriosis. Fish Shellfish Immunol. 7, 227234.

Le Moullac, G., Soyez, C., Saulnier, D., Ansquer, D., Acvarre, J.-C., Levy, P., 1998. Effect of hypoxic stress on the immune response and the resistance to vibriosis of the shrimp Penaeus stylirostris. Fish and Shellfish Immunol. 8, 621-629.

Le Moullac, G., Haffner, P., 2000. Environmental factors affecting immune responses in Crustacea. Aquaculture 191, 121-131.

Lignot, J. H., Charmantier, G., Cochard, J.-C., 1998. Effect of an organophosphorus insecticide, fenitrothion, on survival, osmoregulation, and acetylcholinesterase activity in different life stages of two penaeid shrimps: Penaeus stylirostris and Penaeus vannamei (Crustacea, Decapoda). J. Shellfish Research 17, 1251-1258.

Lignot, J. H., Spanings-Pierrot, C., Charmantier, G., 2000. Osmoregulatory capacity as a tool in monitoring the physiological condition and the effect of stress in crustaceans. Aquaculture 191, 209-245.

Lignot, J. H., Cochard, J.-C., Soyez, C., Lemaire, P., Charmantier, G., 1999. Osmoregulatory capacity according to nutritional status, molt stage and body weight in Penaeus stylirostris. Aquaculture 170, 79-92.

Mermoud, I., Costa, R., Ferré, O., Goarant, C., Haffner, P., 1998. "Syndrome 93" in New Caledonian outdoor rearing ponds of Penaeus stylirostris: history and description of three major outbreaks. Aquaculture 164, 323-335.

Mugnier, C., Justou C., 2004. Combined effect of external ammonia and molt stage on the blue shrimp Litopenaeus stylirostris physiological response. J. Exp. Mar. Biol. Ecol. 309, $35-46$.

Ocampo, L., Villarreal, H., Vargas, M., Portillo, G., Magallon, F., 2000. Effect of dissolved oxygen and temperature on growth, survival and body composition of juvenile Farfantepenaeus californiensis (Holmes). Aquaculture Research 31, 167-171.

Péqueux, A., 1995. Osmotic regulation in crustaceans. J. Crustacean Biol. 15, 1-60. 
Soyez, C., 1997. Evaluation des conséquences d'une situation hypoxique simulée sur la capacité osmorégulatrice des crevettes d'élevage, $\underline{\text { Penaeus stylirostris et Penaeus vannamei. }}$ Internal Report, COP IFREMER, Tahiti, 50 pp.

Stern, S., Cohen, D., 1982. Oxygen consumption and ammonia excretion during the molt cycle of the freshwater prawn Macrobrachium rosenbergii (De Man). Comp. Biochem. Physiol. 73A, 417-419.

Truchot, J.-P., Jouve-Duhamel, A., 1983. Consommation d'oxygène de la crevette japonaise,

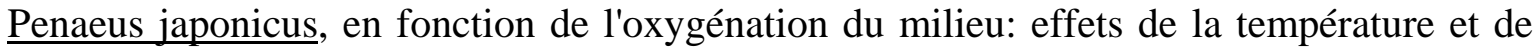
l'acclimatation à des conditions ambiantes hypoxiques. In: IFREMER (Ed), Bases Biologiques de l'Aquaculture. Montpellier, France, vol. 1 pp. 245-254.

Wajsbrot, N., Gasith, A., Krom, M. D., Samocha, T. M., 1990. Effect of dissolved oxygen and the molt stage on the acute toxicity of ammonia to juvenile green tiger prawn Penaeus semisulcatus. Environ. Toxicol. Chem. 9, 497-504. 